\title{
USING TYRES WASTES AS AGGREGATES IN CONCRETE TO FORM RUBCRETE - MIX FOR ENGINEERING APPLICATIONS
}

\author{
G. Nagesh Kumar ${ }^{1}$, V. Sandeep ${ }^{2}$, Ch. Sudharani ${ }^{3}$ \\ ${ }^{1}$ Sr. Assistant Professor, Department of Civil Engineering, G. Pulla Reddy Engineering College (Autonomous), \\ Kurnool, Andhra Pradesh, India \\ ${ }^{2}$ PG Student, Department of Civil Engineering, G. Pulla Reddy Engineering College (Autonomous), Kurnool, Andhra \\ Pradesh, India. \\ ${ }^{3}$ Associate Professor, Department of Civil Engineering, Sri Venkateswara University College of Engineering \\ (Autonomous), Tirupati, Andhra Pradesh, India.
}

\begin{abstract}
This paper presents the results, obtained after replacement of fine and coarse aggregates, in concrete mix, with tyre rubber. The tyre rubber, which has been used in the present study, is obtained after the mechanical trituration process of post - consumed tyres from trucks. Researchers have investigated, over the years, the use of recycled tyre rubber waste as a replacement for aggregate in concrete and its effectiveness. "Rubcrete-Mix" which would result from such replacement is found to have many engineering applications and holds promise in future. Rubcrete also possesses good mechanical properties and is considered to be one of the best and economical ways of recycling the used tyres. The present experimental study has the aim of arriving at the optimum quantity of the replacement material for the aggregates in concrete mixtures, for various engineering applications. For achieving a proper bond with the surrounding concrete paste, the recycled aggregates have been designed with respect to their size, shape and gradation. With the water-cement ratio being kept constant fine and coarse aggregate has been replaced with tyre rubber powder and chipped rubber and also cement has been replaced with silica fume. In preparing the concrete, Portland slag cement has been used along with super plasticizer less than $1 \%$ by weight of cement to achieve required workability of the resulting concrete. Furthermore, durability studies have been conducted and mixes have been designed for M30 grade concrete.
\end{abstract}

Keywords: Concrete Mix, Mechanical Properties, Rubber Powder, Chipped Rubber, Silica fume.

\section{INTRODUCTION}

India has taken step to move forward in infrastructures towards the growth of globalization. Dumping of wastes causes serious health effects and creates environmental problems. Now days vehicles are a major tool to everyone for a means of transportation along with this production of tyres are developing tremendously. After using these worn out tyres which may be throw on open grounds, then these places may turns to landfills. These tyre wastes slowly raised enormously due to these depletion of land filling occurs. Furthermore, these sites may become places to grow rats, and provide place for mosquitoes' breeding. Accumulation of these stock piles of tyres will not degrade easily but it takes more than 100 years of time because due to presence of cross - links between the rubber polymer chains. Since tyres are made from Petroleum by - Products like methane hence which causes fire accidents while burning an acrid black plume evolves and which releases a toxic gases in air when dissolves in water it may pollute the water and causes dreadful diseases to human beings and organisms. It is necessary to have a clear awareness on utilizing industrial wastes for recycling in concrete, Otherwise, these wastes may shows a huge impact on environment. It is an excellent way for the conservation of traditional aggregates in environment. Recently, our Prime Minister of India Sri Narendhra Modi Garu gave an elaborate speech at Delhi in Swacha Bharat Programm about eradication of pollution in environment on the October 2, 2014 it is the desire of our father of nation called Mahatma Gandhi. Our Governor Sri Narasimhan Garu also invited us to strive hard deligently to keep our surroundings clean and green. In past many researchers conducted research and presented the results on this rubberized concrete. The size, shape and gradation play a major role in bonding with the surrounding concrete paste in achieving strength. Most of the experiments performed by collecting a tyre wastes from trucks after removing the textile component and steel fibers. In some occasions the rubber wastes are chemically pretreated to improve the properties of concrete. Gradually, many researchers shown interest to do research beyond of this using waste rubber in concrete. Barluenga and Hernandez - Olivares (2004) ${ }^{[1]}$ has been observed that reduction of spalling damage and improve in fire resistance by using tyre rubber in high - strength concrete slabs. Batayneh et al., (2008) ${ }^{[2]}$ suggested that the usage of rubber in concrete is not recommended where high strength is required. It should be useful only where the high strength is not required.Ganjian et al., (2009) ${ }^{[3]}$ were replaced coarse aggregate with tyre rubber in concrete. They found that by using tyre rubber in concrete it yields to give very less compressive strength than when natural coarse aggregate used in concrete.Guneyisi, E., Gesoglu, M. and Ozturan (2004) ${ }^{[4]}$ were presented that the chloride ion penetration the 
degree of penetration is decreased in rubberized concrete, it mainly depends up on the rubber content in presence of both silica fume and without silica fume, it will accounted for a particular w/c ratio and curing period. Hernandez - Olivares et al., (2000) ${ }^{[5]}$ In his investigations observed that the elastic modulus varies either under static or dynamic load increases with age through experimentally.Najim and Hall $(2005)^{[6]}$ observed that rubber incorporated mixes produces very low unit weight mixes and with high air contents. By incorporating rubber in concrete it improves not only dynamic loading behavior but also impact, vibration and absorption characteristics. Olivares et al., (2006) [7] investigated of about fatigue behavior of tyre rubber incorporated in concrete and also its applications on pavements. Siddique and Naik $(2004)^{[8]}$ they reported that and gave a brief studies on using tyre rubber in concrete they found that by the addition of tyre rubber in concrete even though it reduces the strength of the concrete but the main benefit is that it reduces the mass density to as low as $1750 \mathrm{Kg} / \mathrm{m}^{3}$. Topcu and Bilir (2009) ${ }^{[9]}$ has been reported that by adding tyre rubber in concrete it yields to give very low young's Moduli its value was 10,000 mpa because tyre rubber softens the elastic stress - strain response. However, Turatsinze et al., (2006) ${ }^{[10]}$ has been observed that in his investigation by increasing the quantity of rubber shreds in concrete it will reduces the crack length and width due to shrinkage and it makes more delay of onset time of cracking. Yesilata, et al., (2009) ${ }^{[11]}$ studied about the thermal properties as a part in his research by adding shredded wastes polyethylene bottles and automobile tyres. The thermal transmittance of the concrete samples will be effectively determined by using dynamic adiabatic - box technique through carrying out thermal tests. Yesilata, et al., (2010) ${ }^{[12]}$ has investigated about the thermal behavior of a building structure by using rubberized concrete exterior walls.

In this investigation the fine aggregate and coarse aggregate was replaced with the Rubber powder and Chipped Rubber, finally the Portland slag cement was replaced by silica fume in certain percentages to observe those influences on mechanical properties in concrete. The effects of water absorption, temperature, density and thermal insulating properties including durability properties were also studied.

\section{EXPERIMENTAL DETAILS}

\subsection{Materials}

\subsubsection{Portland Slag Cement}

Portland Slag Cement (PSC), which conforms to 33 grade of IS 455: 1989, was used. The specific gravity of Portland slag cement was 3.1 .

\subsubsection{Rubber Powder}

The Rubber powder will be forms by passing tyre rubber through rotating corrugated steel drums. The obtained material will have very large surface area. It will be useful to replace fine aggregate. The specific gravity of Rubber Powder is 0.55 .

\subsubsection{Chipped Rubber}

It is used to replace the coarse aggregate and having the dimension of about $20 \mathrm{~mm}$. The specific gravity of Chipped Rubber is 1.106 .

\subsubsection{Aggregates}

Coarse aggregate from stone crusher having a nominal maximum size of $20 \mathrm{~mm}$ was used. The specific gravity of coarse aggregate was 2.74. River Sand was used as a fine aggregate in mix of having a nominal maximum size of 4.75 $\mathrm{mm}$ was used. The specific gravity of fine aggregate was 2.65 .

\subsubsection{Silica Fume}

The silica fume - Astra chemicals Lit-Chennai which conform to ASTM C 1240 and IS 15388: 2003 was used in this investigation. The specific gravity of silica fume is 2.20 .

\subsubsection{Super Plasticizer}

Conplast SP430 it will be appear in brown liquid and significantly reduces water demand in a concrete mix to improve the workability. The specific gravity of Conplast SP430 was 1.18 .

\subsection{Mix Proportion}

The mix proportions of different types of percentages of replacement mixes and obtained quantities for mixes were tabulated as below. Table 1 shows the mix proportions for the percentage replacement of fine aggregate with Rubber powder. Table 2 represents the mix proportions for the percentage replacement of coarse aggregate with chipped rubber. Table 3 gives the mix proportions for the percentage replacement of cement with Silica fume. Finally Table 4 includes the mix proportions for the percentage replacement of cement with Silica fume and also the fine aggregate with Rubber Powder. Mix design procedure followed according to IS 10262: 2009. All mix proportions are designed with a slump ranging from $75-100 \mathrm{~mm}$, keeping the water content constant at $157 \mathrm{~kg} / \mathrm{m}^{3}$, with the addition of super plasticizer the required workability has been achieved. The water cement ratio of 0.40 is kept constant for all mixes. Fine aggregate was replaced by Rubber Powder varying from $10 \%$ to $40 \%$ and coarse aggregate was replaced by Chipped Rubber constantly $2.5 \%$ by weight. Cement was replaced by Silica fume varying from $5 \%$ to $15 \%$ by weight of cement. 
Table - 1: Percentage of Fine Aggregate replaced with Rubber Powder.

\begin{tabular}{|l|l|l|l|l|l|l|}
\hline \multirow{2}{*}{$\begin{array}{l}\text { w/c } \\
\text { ratio }\end{array}$} & Water & Cement & $\begin{array}{l}\text { Fine } \\
\text { Aggregate }\end{array}$ & $\begin{array}{l}\text { Coarse } \\
\text { Aggregate }\end{array}$ & \multicolumn{2}{|l|}{ Rubber Powder } \\
\hline 0.4 & 157 & 394 & 717.99 & 1206.82 & $0 \%$ & 0 \\
\hline 0.4 & 157 & 394 & 646.2 & 1206.82 & $10 \%$ & 14.9 \\
\hline 0.4 & 157 & 394 & 574.39 & 1206.82 & $20 \%$ & 29.8 \\
\hline 0.4 & 157 & 394 & 502.59 & 1206.82 & $30 \%$ & 44.7 \\
\hline 0.4 & 157 & 394 & 430.79 & 1206.82 & $40 \%$ & 59.6 \\
\hline
\end{tabular}

Table - 2: Replacement of Aggregates with Rubber Powder and Chipped Rubber

\begin{tabular}{|c|c|c|c|c|c|c|c|c|}
\hline \multirow[b]{2}{*}{$\begin{array}{l}\text { w/c } \\
\text { ratio }\end{array}$} & \multirow{2}{*}{$\begin{array}{l}\text { Water } \\
\left(\mathrm{kg} / \mathrm{m}^{3}\right)\end{array}$} & \multirow{2}{*}{$\begin{array}{l}\text { Cement } \\
\left(\mathrm{kg} / \mathrm{m}^{3}\right)\end{array}$} & \multirow{2}{*}{$\begin{array}{l}\begin{array}{l}\text { Fine } \\
\text { Aggregate }\end{array} \\
\left(\mathrm{kg} / \mathrm{m}^{3}\right)\end{array}$} & \multicolumn{2}{|c|}{ Rubber Powder } & \multicolumn{2}{|c|}{ Chipped Rubber } & \multirow{2}{*}{$\begin{array}{l}\begin{array}{l}\text { Coarse } \\
\text { Aggregate }\end{array} \\
\left(\mathrm{kg} / \mathrm{m}^{3}\right)\end{array}$} \\
\hline & & & & $\begin{array}{l}\text { \% } \\
\text { Replaced }\end{array}$ & $\left(\mathrm{kg} / \mathrm{m}^{3}\right)$ & $\begin{array}{l}\% \\
\text { Replaced }\end{array}$ & $\left(\mathrm{kg} / \mathrm{m}^{3}\right)$ & \\
\hline 0.4 & 157 & 394 & 682.09 & $5 \%$ & 7.45 & $2.50 \%$ & 30.17 & 1176.65 \\
\hline 0.4 & 157 & 394 & 646.19 & $10 \%$ & 14.9 & $2.50 \%$ & 30.17 & 1176.65 \\
\hline 0.4 & 157 & 394 & 610.29 & $15 \%$ & 22.35 & $2.50 \%$ & 30.17 & 1176.65 \\
\hline 0.4 & 157 & 394 & 574.39 & $20 \%$ & 29.8 & $2.50 \%$ & 30.17 & 1176.65 \\
\hline
\end{tabular}

Table - 3: Replacement of cement with silica fume

\begin{tabular}{|c|c|c|c|c|c|c|}
\hline \multirow[b]{2}{*}{$\begin{array}{l}\mathrm{w} / \mathrm{c} \\
\text { ratio }\end{array}$} & \multirow{2}{*}{$\begin{array}{l}\text { Water } \\
\left(\mathrm{kg} / \mathrm{m}^{3}\right)\end{array}$} & \multirow{2}{*}{$\begin{array}{l}\text { Cement } \\
\left(\mathrm{kg} / \mathrm{m}^{3}\right)\end{array}$} & \multicolumn{2}{|c|}{ Silica fume } & \multirow{2}{*}{$\begin{array}{l}\begin{array}{l}\text { Fine } \\
\text { Aggregate }\end{array} \\
\left(\mathrm{kg} / \mathrm{m}^{3}\right)\end{array}$} & \multirow{2}{*}{$\begin{array}{l}\begin{array}{l}\text { Coarse } \\
\text { Aggregate }\end{array} \\
\left(\mathrm{kg} / \mathrm{m}^{3}\right)\end{array}$} \\
\hline & & & $\begin{array}{l}\% \\
\text { Replaced }\end{array}$ & $\left(\mathrm{kg} / \mathrm{m}^{3}\right)$ & & \\
\hline 0.4 & 157 & 374.3 & $5 \%$ & 19.7 & 717.99 & 1206.82 \\
\hline 0.4 & 157 & 354.6 & $10 \%$ & 39.4 & 717.99 & 1206.82 \\
\hline 0.4 & 157 & 334.9 & $15 \%$ & 59.1 & 717.99 & 1206.82 \\
\hline
\end{tabular}

Table - 4: Replacement of cement with silica fume and Fine aggregate with Rubber Powder

\begin{tabular}{|c|c|c|c|c|c|c|c|c|}
\hline \multirow[b]{2}{*}{$\begin{array}{l}\text { w/c } \\
\text { ratio }\end{array}$} & \multirow{2}{*}{$\begin{array}{l}\text { Water } \\
\left(\mathrm{kg} / \mathrm{m}^{3}\right)\end{array}$} & \multirow{2}{*}{$\begin{array}{l}\text { Cement } \\
\left(\mathrm{kg} / \mathrm{m}^{3}\right)\end{array}$} & \multicolumn{2}{|c|}{ silica fume } & \multirow{2}{*}{$\begin{array}{l}\text { Fine } \\
\text { Aggregate } \\
\left(\mathrm{kg} / \mathrm{m}^{3}\right)\end{array}$} & \multicolumn{2}{|c|}{ Rubber Powder } & \multirow{2}{*}{$\begin{array}{l}\begin{array}{l}\text { Coarse } \\
\text { Aggregate }\end{array} \\
\left(\mathrm{kg} / \mathrm{m}^{3}\right)\end{array}$} \\
\hline & & & $\begin{array}{l}\% \\
\text { Replaced }\end{array}$ & $\left(\mathrm{kg} / \mathrm{m}^{3}\right)$ & & $\begin{array}{l}\% \\
\text { Replaced }\end{array}$ & $\left(\mathrm{kg} / \mathrm{m}^{3}\right)$ & \\
\hline 0.4 & 157 & 374.3 & $5 \%$ & 19.7 & 646.2 & $10 \%$ & 14.9 & 1206.82 \\
\hline 0.4 & 157 & 354.6 & $10 \%$ & 39.4 & 646.2 & $10 \%$ & 14.9 & 1206.82 \\
\hline 0.4 & 157 & 334.9 & $15 \%$ & 59.1 & 646.2 & $10 \%$ & 14.9 & 1206.82 \\
\hline
\end{tabular}

\subsection{Preparation and Casting of Specimens}

A total of 15 mixes were prepared in this study and 45 cube samples were prepared $(150 \times 150$ x $150 \mathrm{~mm})$ for conducting the compression test. Also, 45 samples of beams $(100 \times 100 \times 500) \mathrm{mm}$ for flexural test and 45 samples of cylinders (150 diameter x 300 height) $\mathrm{mm}$ for split tensile test and modulus of elasticity test were prepared. The samples of 3 cubes, 3 cylinders and 3 beams of each different types of percentage replacement mixes of fine aggregate with Rubber powder in various percentages of $10 \%, 20 \%, 30 \%$ and $40 \%$, Coarse aggregate was replaced with Chipped Rubber of $2.5 \%$ it was found to be optimum. Finally Portland Slag Cement was replaced with Silica
Fume in different percentages of varying from 5\%,10\% and $15 \%$. These mixes were casted, kept curing for 28 days and after they were tested for Compression strength, Split Tensile strength and Flexural strength test has been conducted to respective specimens. Finally, under durability studies Rapid chloride ion Permeability Test was performed. For this test three sets of cylindrical specimens of size 100 $\mathrm{mm}$ diameter X $50 \mathrm{~mm}$ length has been prepared and it was tested for plain concrete, Replaced mixes of fine aggregate with rubber powder and in another set both fine aggregate, cement was replaced with Rubber Powder and Silica Fume. 


\section{RESULTS AND DISCUSSIONS}

\subsection{Compression Strength}

The cubes were cast and tested after 28 days of curing period. Results were represented in figure 1 it was indicating the strength pattern when Fine aggregate, Coarse aggregate and Cement was replaced with Rubber Powder, Chipped Rubber and Silica Fume. It was observed that the $40 \%$ of Compression Strength was reduced with increase of replacement of fine aggregate with tyre rubber powder by $40 \%$. Also $36 \%$ reduction of strength was observed when both coarse aggregate and fine aggregate was replaced with Chipped Rubber $2.5 \%$ and Rubber Powder 20\%. In addition to this, $34 \%$ reduction of compressive strength was observed when both cement was replaced with silica fume $15 \%$ and fine aggregate was replaced with Rubber powder $10 \%$. This is due to the weakness of bond between the cement matrix and tyre rubber powder when compared with the sand.

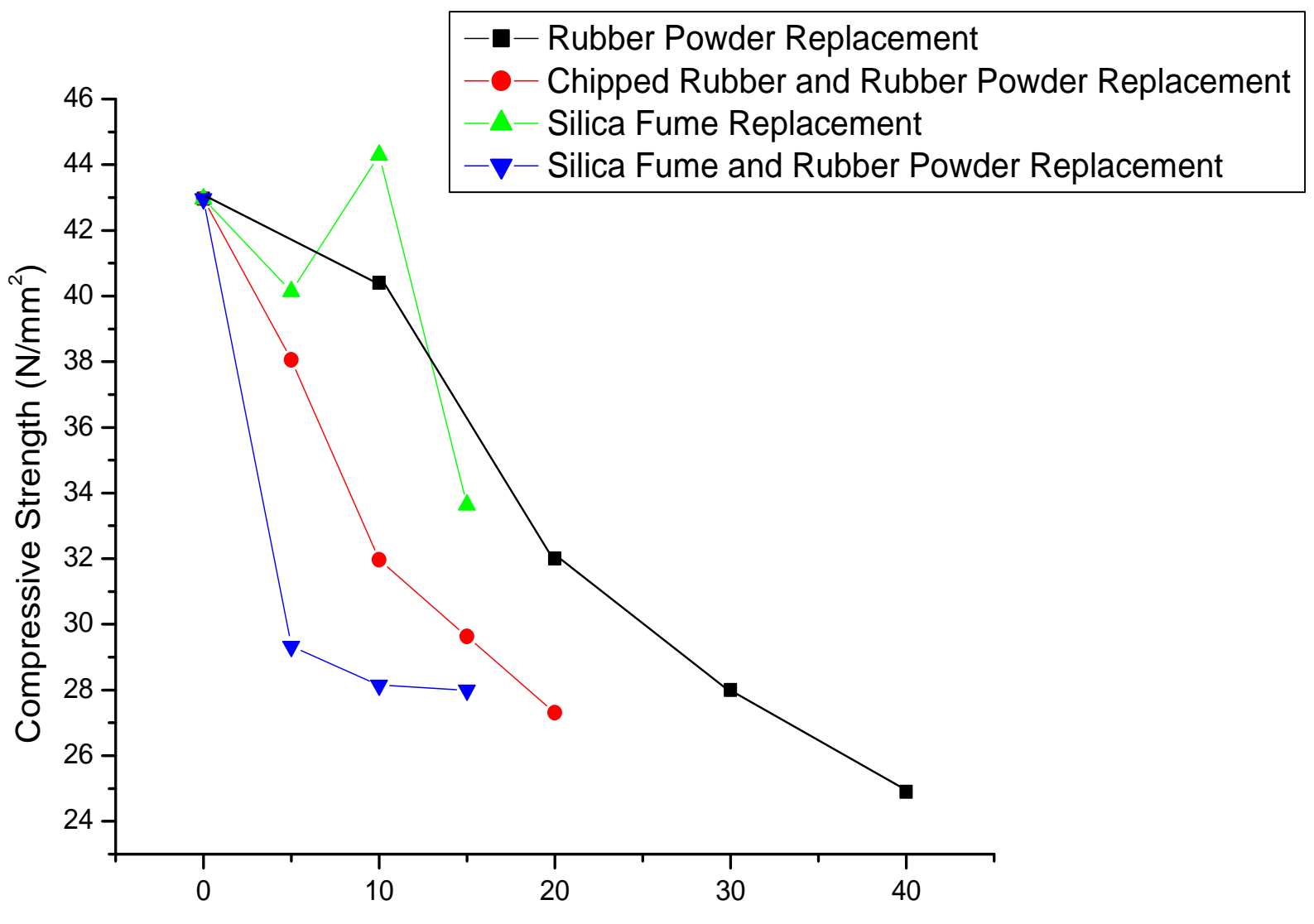

$\%$ of Replacement of Different forms of Rubber Mixes

Fig- 1: Compression Strength of Cubes for 28 days

\subsection{Split Tensile Strength}

The cylinders were cast and tested in the laboratory after the curing period of 28 days. Results are represented in figure 2. Results indicating the strength pattern, when Fine aggregate, Coarse aggregate and Cement was replaced with Rubber Powder, Chipped Rubber and Silica Fume. It was observed that $22 \%$ of split tensile strength was reduced, by increasing the percentage replacement of sand with tyre Rubber Powder up to $40 \%$. Also $21 \%$ reduction of split tensile strength was observed, when both coarse aggregate and fine aggregate were replaced with Chipped Rubber $2.5 \%$ and Rubber Powder $20 \%$. Finally $25 \%$ reduction of strength was observed when replacing of cement with silica fume $15 \%$ and fine aggregate with Rubber Powder $10 \%$. This can be explained by the poor bond between the cement paste and the tyre Rubber Powder. Inter face zone is likely to reduce the bond between the cement paste and the tyre Rubber Powder. 


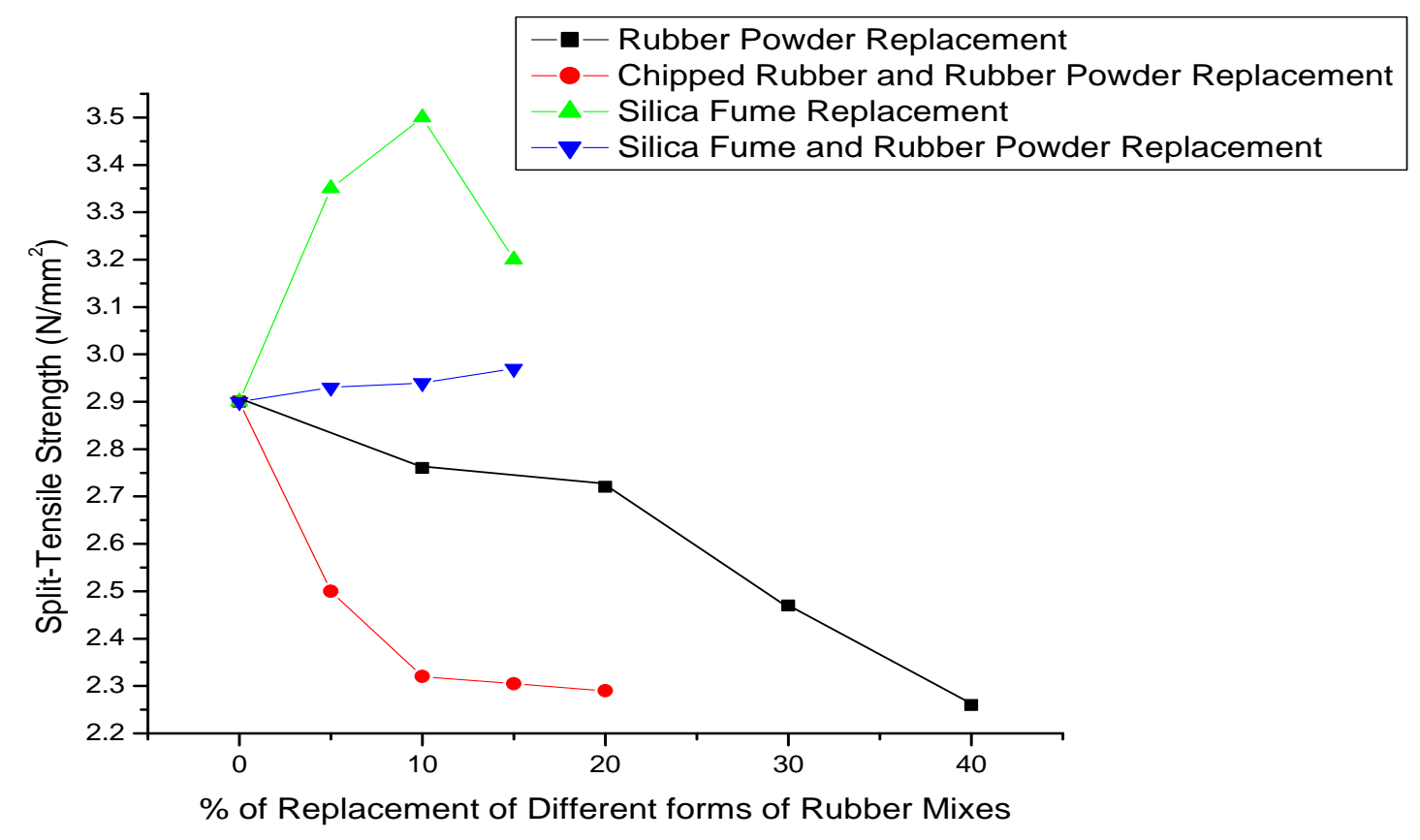

\subsection{Flexural Strength}

Fig- 2: Split Tensile Strength of Cylinders for 28 days

Similarly the flexural strength reduced by increasing replacement of tyre Rubber Powder by $40 \%$ in place of Sand. It was found that $34 \%$. In addition to this $16 \%$ reduction of flexural strength was also observed, when coarse aggregate and fine aggregate were replaced with chipped rubber and tyre rubber powder and 34\% flexural strength reduction was observed when both cement replaced with silica fume and fine aggregate was replaced with tyre Rubber Powder. The likely reason for this reduction of strength is that, there will be a very weak bond between the cement paste and the tyre Rubber Powder. The results are shown in fig.3.

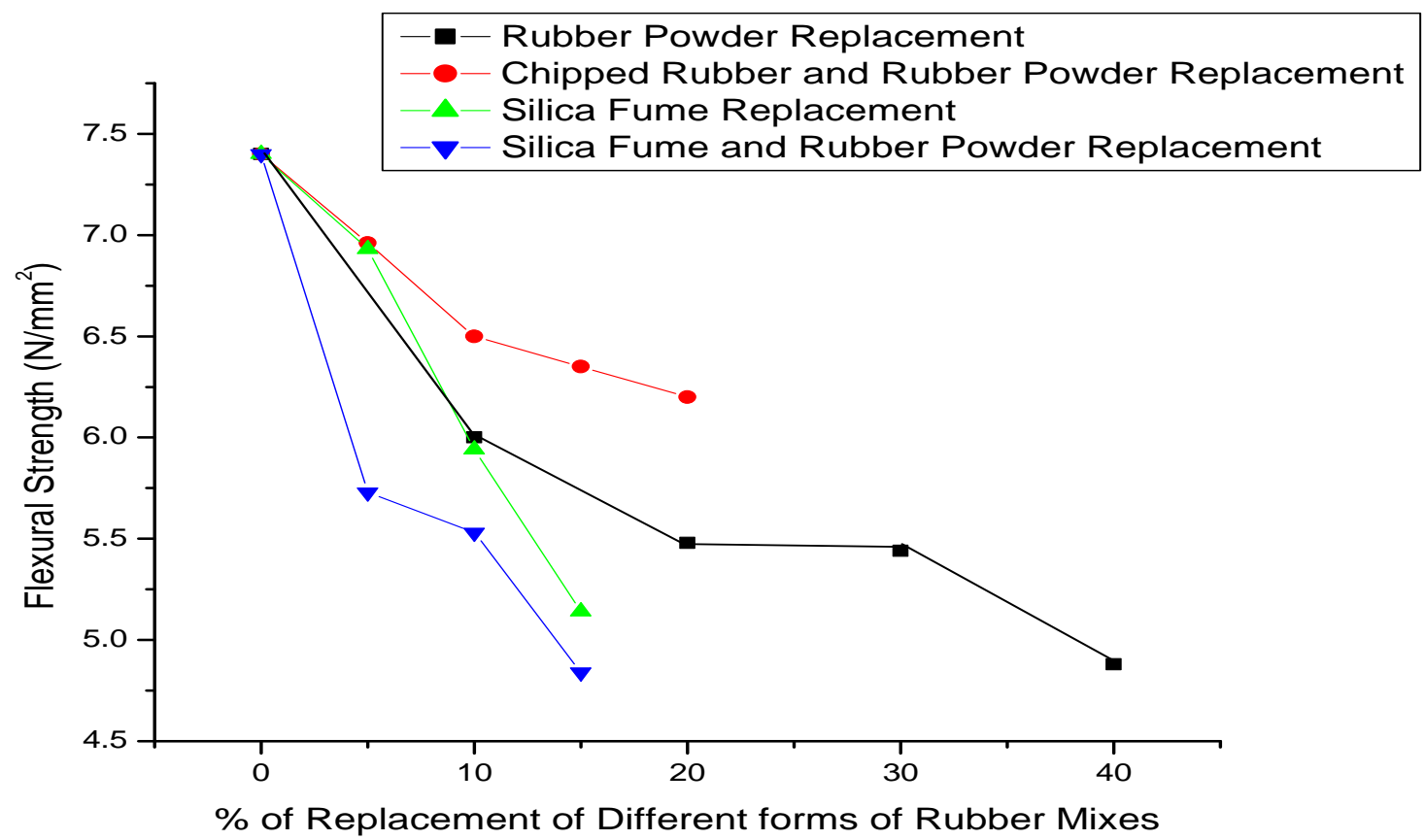

Fig- 3: Flexural Strength of Beams for 28 days 


\subsection{Modulus of Elasticity}

The modulus of elasticity will reduce by increasing the percentage replacement of fine aggregate with tyre Rubber Powder. Even though it reduces but the material will able to withstand against large deformations and material has a much higher elasticity is shown in fig. 4. Stress vs. strain test was conducted for the replaced mixes of fine aggregate with tyre rubber powder and it was represented in fig. 5. Similarly, silica fume was replaced in place of cement and results were represented in fig. 6 . It was observed that the compressive strength reduces for the replaced mixes when compared to control mixture but the rubcrete - mixtures have ability to withstand against dynamic forces without cracking.

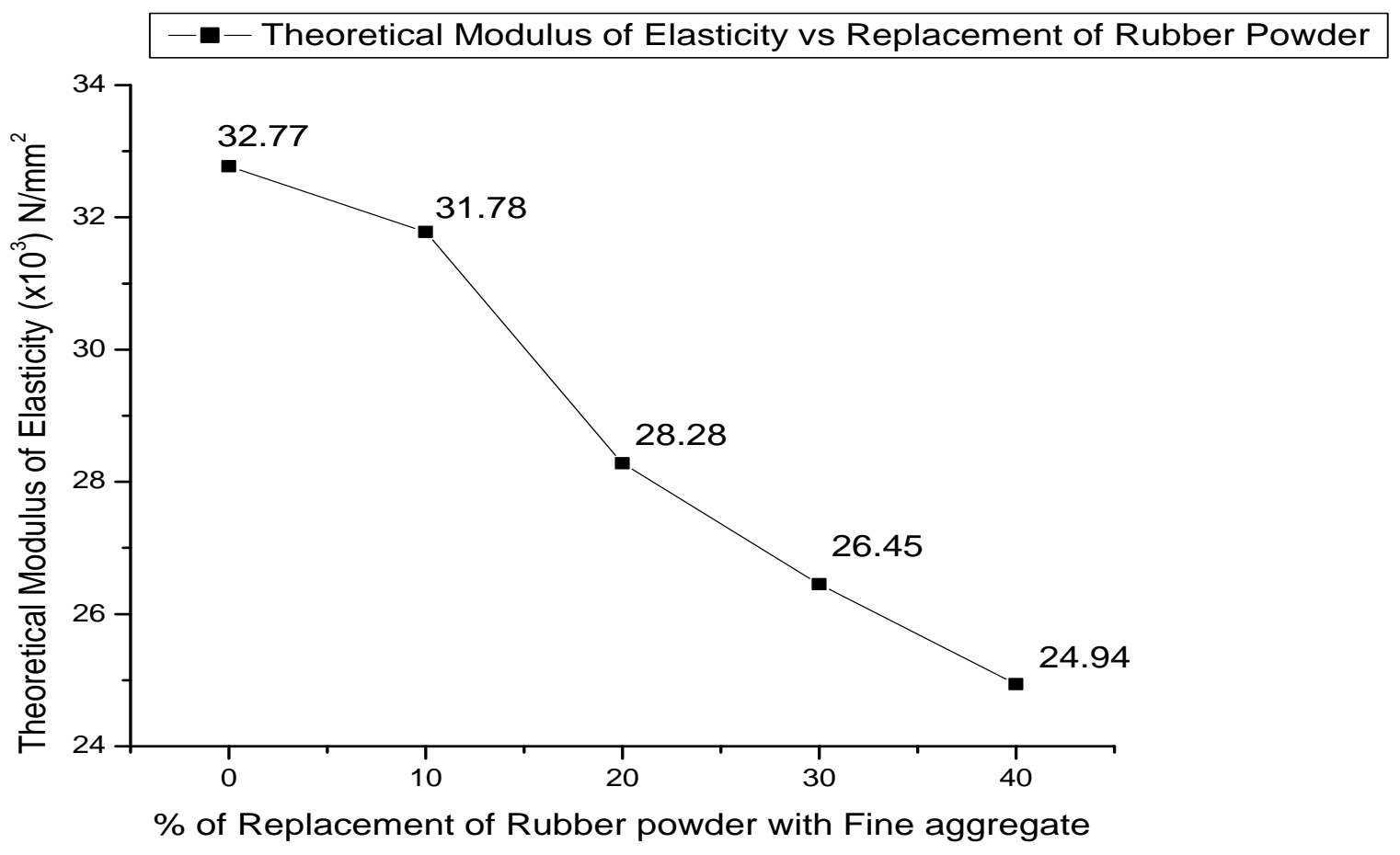

Fig- 4: Variation of Modulus of Elasticity with Replacement of Rubber Powder

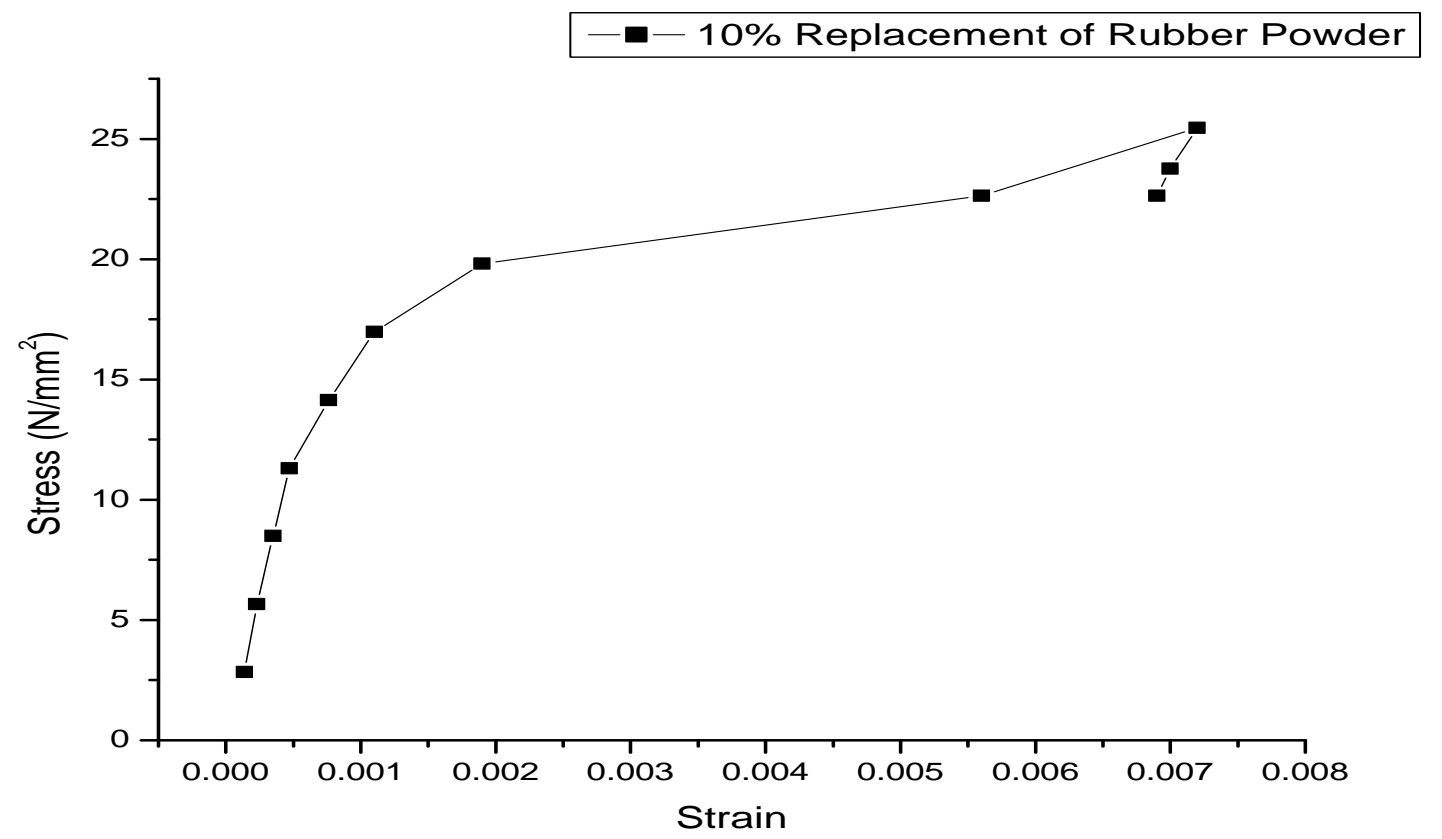

Fig- 5: Stress vs. Strain with Replacement of Rubber Powder 


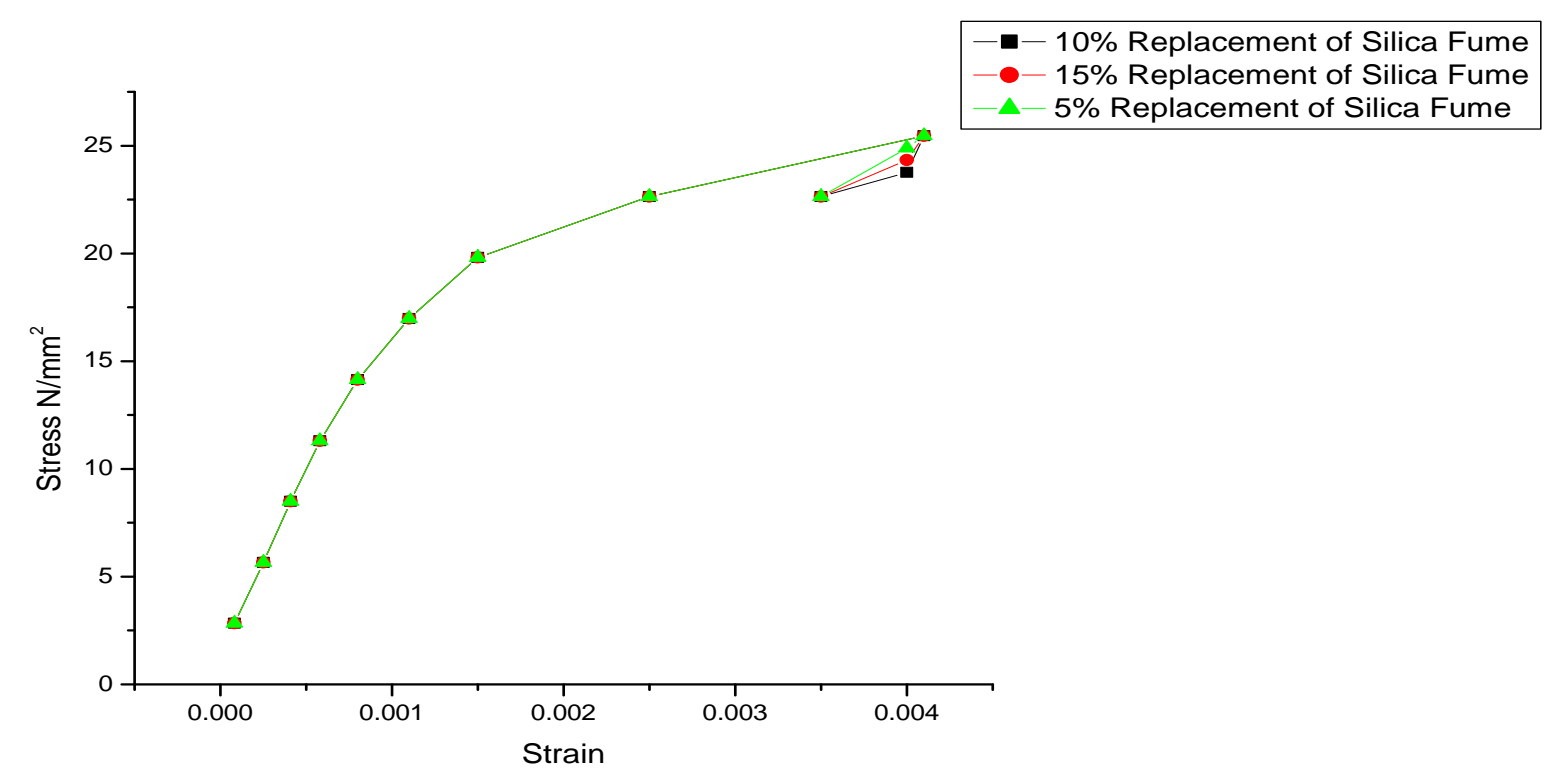

Fig- 6: Stress vs. Strain

\section{Other Properties}

\subsection{Water Absorption}

Water absorption test carried out on concrete cubes and it was found that it will be increases by increasing the content of tyre Rubber Powder in place of sand up to $40 \%$ because the weak bond between the cement paste and the tyre Rubber Powder as a result the vacuums will be increases this leads to the water to penetrate through the interface zone of cement matrix and the tyre Rubber Powder. Also, the tyre rubber particles will have smaller in size as a result it leads to formation of more voids. It will be shown in fig.7.

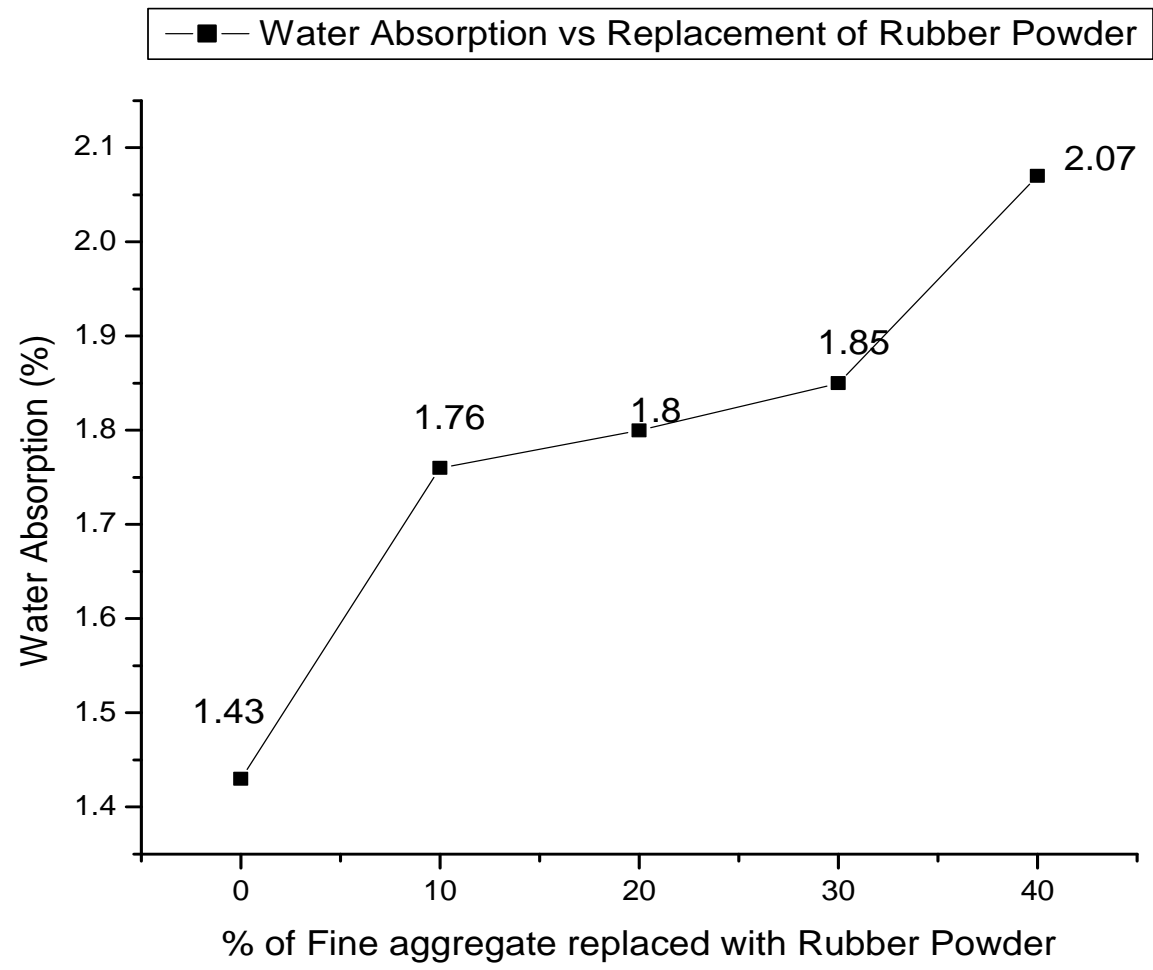

Fig- 7: Water Absorption 


\subsection{Density}

Density will reduce by increasing the percentage replacement of tyre rubber powder in place of sand it was founded that it will be reaches up to 5.7\% when fine aggregate was replaced with tyre Rubber Powder from $0 \%$ to $40 \%$ this is because tyre rubber powder has lower specific gravity than sand. This is shown in fig. 8 .

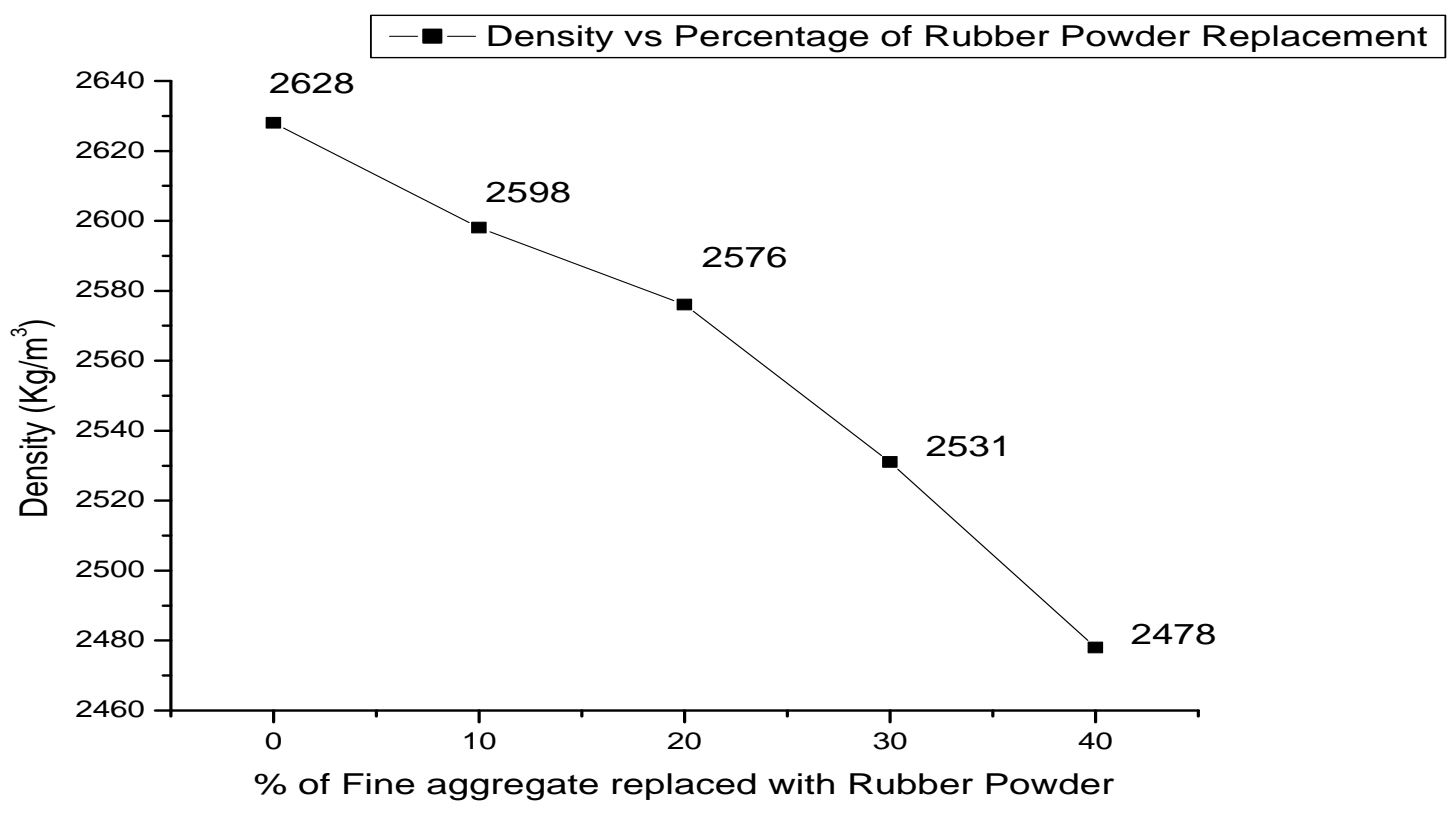

Fig- 8: Density

\subsection{Thermal Insulation}

Thermal insulation test was conducted for the specimens by supplying heat from a constant source of $70^{\circ} \mathrm{C}$ and results were represented in fig.9.The percent reduction in thermal insulation increases as tyre rubber powder replacement increases and it was found that with percentage reduction of $25.71 \%$ to $51.42 \%$ respectively. It was observed that thermal insulation will increase by increasing the percentage replacement of fine aggregate with tyre rubber powder because the tyre rubber powder will have very low density and lower conductivity when compared with sand.

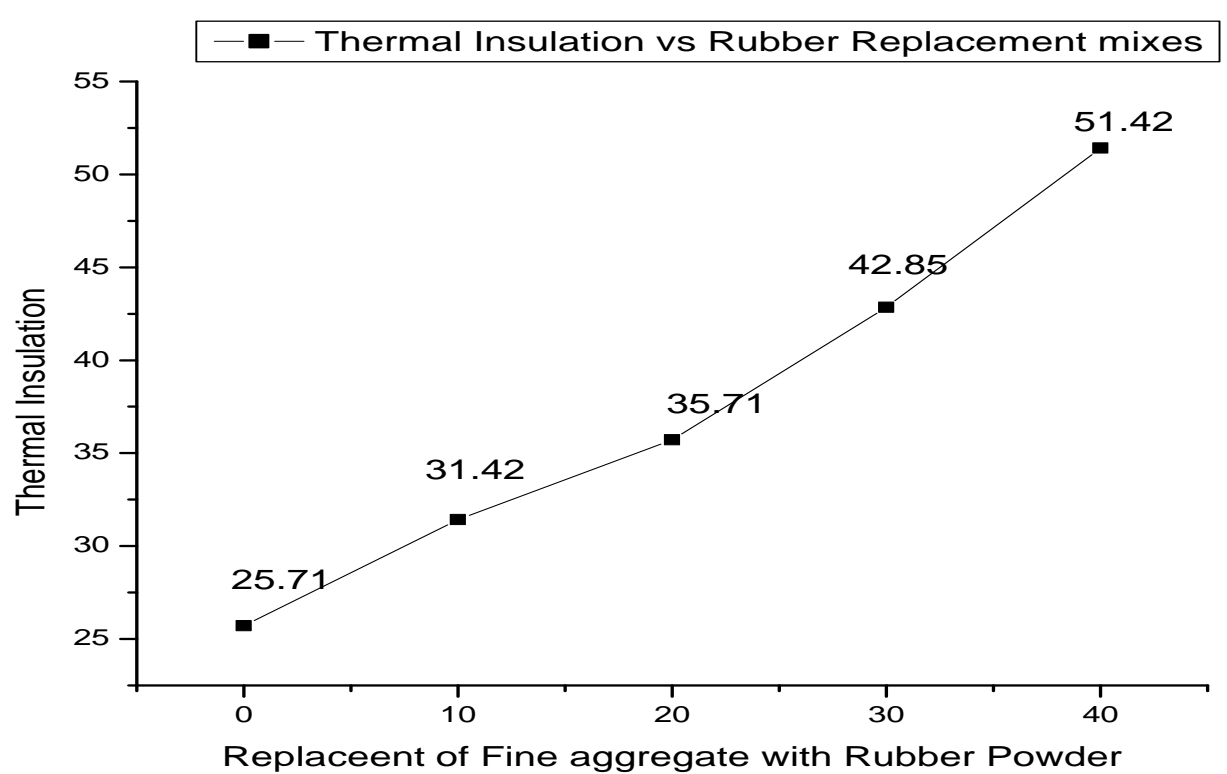

Fig- 9: Thermal Insulation 


\subsection{Rapid Chloride Ion Permeability Test}

Rapid chloride ion permeability test was conducted under durability of concrete and the results are presented in Fig. 10. It was observed that the flow of charge is low in specimens, which are having tyre rubber powder replaced with fine aggregate. From the results, it can be concluded that the rubcrete - mix exhibits low permeability.

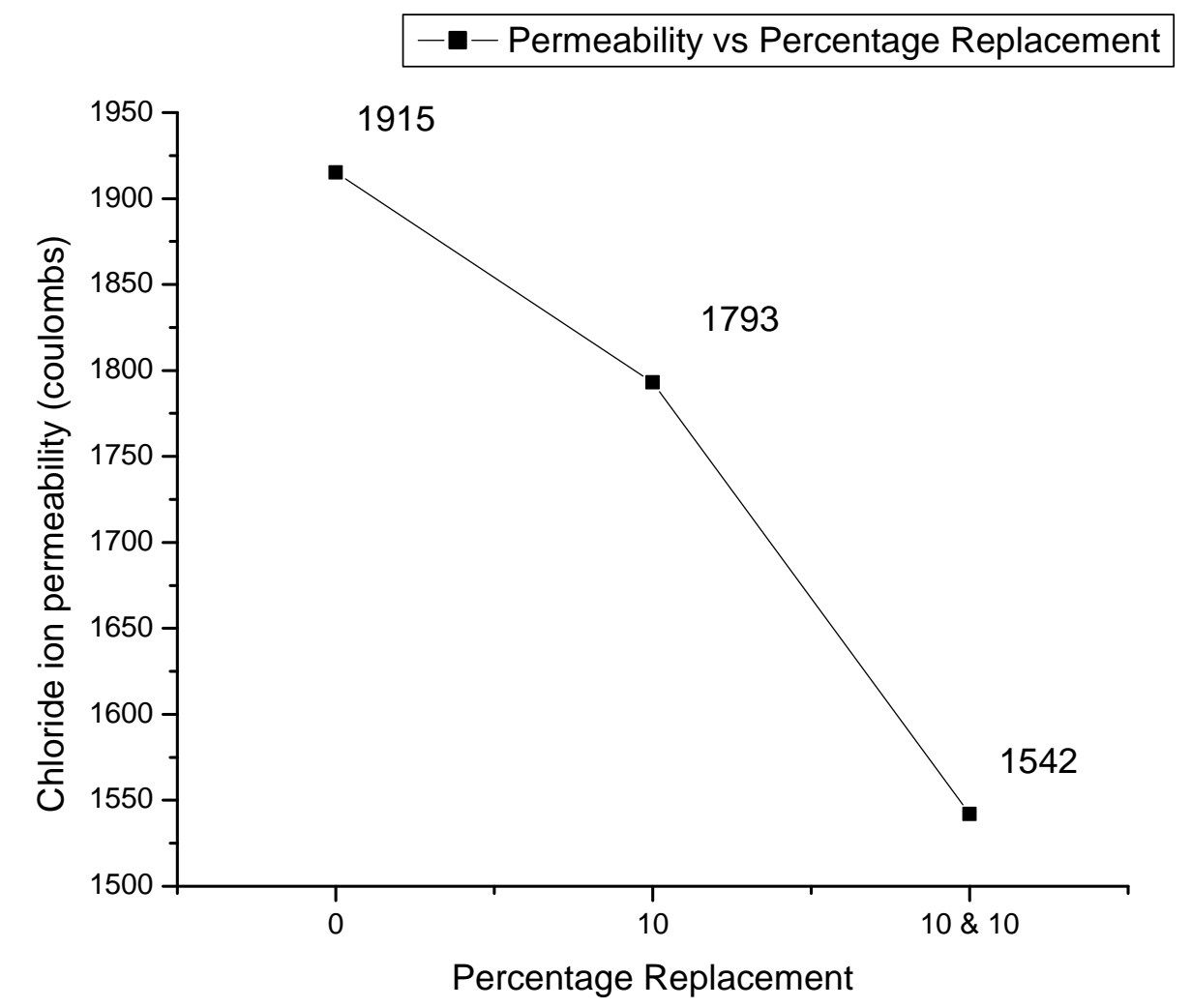

Fig- 10: Rapid Chloride Permeability Test

\section{CONCLUSIONS}

Based on the results and then analysis, the following conclusions have been arrived it. Compressive strength of rubber powder mixtures decreases as the percentage of replacement of sand by rubber powder increases, for various percentages of mixes. Density decreases as the percent of rubber powder replacement increases, for various percentages of mixes. Water absorption increases as percentage of rubber powder content increases. Slump of the concrete ranges from 75 to $100 \mathrm{~mm}$. Modulus of Elasticity decreases as rubber powder replacement increases and higher flexibility was obtained. Thermal insulation increases as rubber powder percentage increases. Optimum replacement of coarse aggregate with chipped rubber was adopted as $2.5 \%$. Rubcrete - Mix is also one form of light weight concrete. Use of alternative for traditional aggregates that have been in use over the years would help in the conservation of environment. Compressive strength improves slightly in the presence of silica fume. Use of tyre rubber powder leads to low permeability value, which can be attributed to its lower density and conductivity. Low permeability can be achieved, by use of silica fume in concrete.

\section{REFERENCES}

[1]. Barluenga, G., Hernandez - Olivares, F., 2004. Fire performance of recycled rubber - filled high - strength concrete. Cement and Concrete Research 34 (2004) pp. 109 $-117$.

[2]. Batayneh M.K, Iqbal M., Ibrahim A., 2008. Promoting the use of crumb rubber concrete in developing countries. Waste Management 28, $2171-2176$.

[3]. Ganjian E., Khorami, M., and Maghsoudi, A.A., 2009. Scrap - tyre - rubber replacement for aggregate and filler in concrete. Construction and Building Materials 23 (2009) $1828-1836$.

[4]. Guneyisi, E., Gesoglu, M. and Ozturan, T. 2004. Properties of Rubberized Concretes containing silica fume; cement and concrete research 34: 2309 - 2317.

[5]. Hernandez - Olivares, F., Barluenga, G., Bollati, M., Witoszek, B., 2002. Static and dynamic behavior of recycled tyre rubber - filled concrete. Cement and Concrete Research 32 (10), pp. 1587 - 1596.

[6]. Najim KB. Modulus of elasticity and impact resistance of chopped worn - out tyres concrete. Iraqi J civil Eng 2005; 1 (6): $83-96$. 
[7]. Olivares - Hernandez F, Barluenga G. High strength concrete modified with solid particles recycled from elastomeric materials. In: Konig G, Dehn F, Faust T, editors. Proceedings of the $6^{\text {th }}$ international symposium on high strength/high performance, Leipzig, Germany, 2002. P. $1067-77$

[8]. Siddique R., Naik T. R., 2004. Properties of concrete containing scrap - tyre rubber - an overview, Waste Management 24, PP. 563 - 569.

[9]. Topcu, I. B. and Bilir, T. 2009. Experimental Investigation of some Fresh and Hardened Properties of Rubberized Self - Compacting Concrete. Materials and Design 30:3056 - 3065.

[10]. Turatsinze A, Bonnet B, Granju JL. Mechanical Characterisation of cement - based mortar incorporating rubber aggregates from recycled worn tyres. Build Environ 2005; 40(2):221 - 6 .

[11]. Yesilata, B., IslKer, Y., Turgut, P. (2009). "Thermal insulation enhancement in concretes by adding waste PET and rubber pieces, "Elseveir, Construction and Building Materials, Vol. 23 No. (5), pages $1878-1882$.

[12]. Yesilata, B., Bulut, H. (2011). "Experimental Study On thermal behavior of a building structure using rubberized exterior - walls." Elseveir, Energy and Buildings, Vol. 43, Issues $2-3$, pages $393-399$

\section{List of Indian Standard Codes Referred:}

a. IS 1199:1959 Determination Of Workability Of Concrete.

b. IS516:1959 Methods for Testing For Strength Of Concrete, Bureau Of Indian Standards.

c. IS 383:1970 Standard Specifications For Testing Of Construction Materials, Bureau Of Indian Standards.

d. IS 5816:1999 Splitting Tensile Strength of Concrete Method of Test.

e. IS 10262:2009 (Reaffirmed 2004): Recommended guidelines for concrete mix design, Bureau of Indian Standards.

f. IS 455:1989 Portland slag cement - specification fourth edition Bureau of Indian Standards, New Delhi.

g. IS 456:2000 Plain and Reinforced Concrete - Code of Practice.

\section{BIOGRAPHIES}

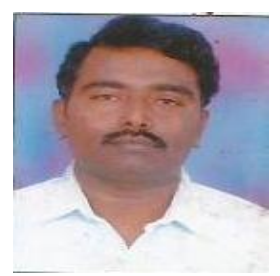

G. Nagesh Kumar He has received his M. Tech degree (Structural Engineering) from JNTU, Anantapur, Andhra Pradesh, India. He is currently pursuing his research under the guidance of Dr. CH. Sudharani at SVU, Tirupati, Andhra Pradesh, India. Presently, he is working as Sr. Asst. Prof in the CED of G. Pulla Reddy Engineering College (Autonomous) and has 28 years of experience in teaching. His research interest includes Material Sciences.

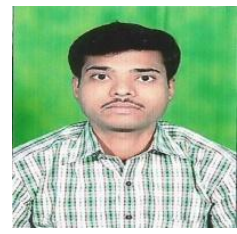

V. Sandeep holds a B. Tech degree (Civil Engineering) JNTU A, Anantapur, India. He is currently Pursuing his PG degree in Structural Engineering under the guidance of G. Nagesh Kumar Andhra Pradesh, India. His present area of research interest is in Material sciences.

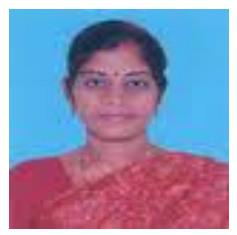

Dr. CH. Sudharani is currently working as Associate Professor in the civil Engineering Department of SVU college of Engineering (Autonomous), Tirupati, India. She has an experience of more than a decade in teaching and research. She has guided a number of UG and PG project works. At present, 4 students are pursuing their Doctoral Degree under her guidance. Her area of research interest is ANN modeling in GTE. 